\title{
Hubungan Tingkat Kepatuhan Penderita Tuberkulosis Paru dengan Perilaku Kesehatan, Efek Samping OAT dan Peran PMO pada Pengobatan Fase Intensif di Puskesmas Seberang Padang September 2012 - Januari 2013
}

\author{
Nitari Rahmi ${ }^{1}$, Irvan Medison ${ }^{2}$, Ifdelia Suryadi ${ }^{3}$
}

\begin{abstract}
Abstrak
Indonesia sebagai negara keempat terbesar didunia dalam jumlah penderita tuberkulosis (TB) paru. Pada tahun 2011, di wilayah kota Padang terdapat sebanyak 108 kasus TB paru per 100.000 penduduk. Kasus TB paru banyak ditemukan di wilayah puskesmas Seberang Padang yaitu sebanyak 46 kasus. Tujuan penelitian ini adalah untuk mengetahui hubungan tingkat kepatuhan berobat penderita TB paru dengan perilaku kesehatan, efek samping Obat Anti Tuberkulosis (OAT) dan peran Pengawas Menelan Obat (PMO) dalam pengobatan fase intensif di puskesmas Seberang Padang. Desain penelitian ini adalah analitik cross sectional dengan menggunakan kuesioner dan wawancara observasional. Populasi dalam penelitian ini adalah seluruh penderita TB paru periode September 2012-Januari 2013 yaitu 34 orang. Analisis statistik yang digunakan adalah chi-square. Hasil penelitian menunjukkan bahwa terdapat hubungan tingkat kepatuhan berobat penderita TB paru dengan perilaku kesehatan $(p=0,00)$ dan peran PMO $(p=0,00)$, tetapi tidak terdapat hubungan dengan efek samping OAT. Disarankan untuk lebih aktif dalam melakukan penyuluhan mengenai penyakit TB paru kepada penderita TB paru dan keluarganya.
\end{abstract}

Kata kunci: kepatuhan berobat, perilaku kesehatan, PMO, efek samping OAT, tuberkulosis

\section{Abstract}

Indonesia is the fourth highest of Tuberkulosis (TB) cases. In 2011, the city of Padang has 108 cases in 100.000 population. Pulmonary TB cases are founded in the region of Public Health Center (PHC) of Seberang Padang by 46 cases. The objective of this study was to determine the correlation between the compliance treatment of pulmonary TB patients and health behaviors, side effects of drugs and the role of a treatment supporter in the intensive phase of treatment at PHC of Seberang Padang. The design of this study was cross sectional's analitic that used quetionnaires and interviews with observational. The population were all patients of pulmonary TB in period September 2012-January 2013 is 34 peoples. Statistical analysis has used chi-square. The results showed, there is a correlation between the compliance treatment of pulmonary TB patients with health behaviors $(p=0,00)$ and the role of the PMO $(p=0,00)$, but there are no correlation with the side effects of drugs. Suggested to be more active in the education of pulmonary TB disease to pulmonary TB patients and their families.

Keywords: the compliance treatment, health behavior, PMO, side effects of drugs, tuberculosis

Affiliasi penulis: 1. Prodi Profesi Dokter FK Unand (Fakultas Kedokteran Universitas Andalas Padang), 2. Bagian Paru FK Unand/ RSUP Dr. M. Djamil Padang, 3. Bagian Histologi FK Unand

Korespondensi: Nitari Rahmi Putri, Email:

deparadise_25@yahoo.com, Telp : 085274525729

\section{PENDAHULUAN}

Tuberkulosis (TB) Paru adalah penyakit menular yang disebabkan kuman Mycobacterium tuberkulosis dan bersifat kronis. Pengobatan TB paru memerlukan waktu yang panjang, yaitu selama enam 
bulan. World Health Organization (WHO) yang dikutip oleh Aditama dan Tjandra $\mathrm{Y}$, telah mencanangkan penyakit TB Paru sebagai salah satu kedaruratan dunia atau emerging disease terutama terjadi pada negara-negara berkembang diantaranya yaitu Indonesia. $^{1}$

Berdasarkan Kemenkes RI, angka insiden TB Paru BTA(+) pada tahun 2011 sebesar 119 per 100.000 penduduk. Data Dinas Kesehatan Kota tahun 2011, di wilayah kota Padang terdapat sebanyak 111 kasus TB Paru BTA (+) per 100.000 penduduk. Pencapaian angka kesembuhan, menunjukkan presentasi pasien TB Paru BTA (+) yang sembuh setelah pengobatan dengan pencapaian sebesar $85 \%$. $^{2,3}$

Keberhasilan pengobatan dengan penerapkan strategi Directly Observed Treatment Short-course (DOTS) yaitu pengobatan jangka pendek yang standar bagi semua kasus TB dengan tatalaksana kasus yang tepat, termasuk pengawasan langsung pengobatan oleh Pengawas Menelan Obat (PMO). ${ }^{4}$

Dikawasan Puskesmas Seberang Padang dengan jumlah penduduk sebanyak 16.780, pada tahun 2011 terdapat kasus TB Paru BTA (+) sebanyak 48 kasus atau 286 per 100.000 penduduk, dari 48 kasus, sebanyak 32 orang dinyatakan sembuh (angka kesembuhan 68,1\%) Berdasarkan data tersebut, dapat disimpulkan bahwa puskesmas Seberang Padang belum bisa mencapai target yang ditetapkan. ${ }^{5}$

Berdasarkan hasil penelitian oleh Badan Penelitian dan Pengembangan Kesehatan Republik Indonesia, salah satu faktor sehingga rendahnya cakupan angka kesembuhan yaitu ketidakpatuhan pada pengobatan penderita TB paru. Berdasarkan hasil penelitian Tirtana pada tahun 2011, yaitu berbagai faktor penyebab ketidakpatuhan pengobatan minum obat penderita TB Paru dapat disimpulkan bahwa faktor manusia (baik penderita maupun PMO) sebagai penyebab utama. Dimaksud dengan faktor manusia adalah bagaimana perilaku individu tersebut, diantaranya karakteristik individu, pengetahuan, dan penilaian terhadap sikap pelayanan kesehatan. ${ }^{6,7}$
Beberapa penderita yang mengalami efek samping dari obat anti TB juga memutuskan untuk berhenti berobat. Akhirnya menyebabkan kekebalan ganda kuman TB terhadap obat anti TB (multidrug resistance) dan akan menyebabkan terjadinya epidemi TB yang sulit ditangani. ${ }^{1,3}$

Berdasarkan uraian diatas, maka perlu dilakukan penelitian untuk memperoleh informasi tentang hubungan tingkat kepatuhan berobat penderita TB paru dengan perilaku kesehatan, efek samping OAT, dan peran PMO pada pengobatan fase intensif di Puskesmas Seberang Padang.

\section{METODE}

Penelitian ini adalah studi analitik dengan menggunakan desain cross sectional. Penelitian dilaksanakan di Puskesmas Seberang Padang. Pelaksanaan penelitian dilakukan dari bulan September 2012 sampai Januari 2013 Populasi dalam penelitian ini adalah seluruh penderita TB Paru yang menyelesaikan pengobatan tahap intensif mengikuti program DOTS di Puskesmas Seberang Padang dari September 2012 sampai Januari 2013.

Sampel yang digunakan merupakan seluruh penderita TB Paru yang menyelesaikan pengobatan tahap intensif yang memenuhi kriteria inklusi dan eksklusi yaitu sebanyak 34 orang. Kriteria eksklusi dari penelitian ini adalah responden tidak berhasil ditemui setelah dua kali kunjungan dan responden yang meninggal dunia. Variabel indenpenden dari penelitian ini adalah efek samping OAT, peran PMO, dan perilaku kesehatan, sedangkan variabel dependen, yaitu kepatuhan berobat penderita TB paru.

Langkah-langkah pengolahan data adalah pemeriksaan kelengkapan dan kejelasan data, pemberian kode pada setiap data variabel, memasukkan data dalam program komputer, serta pemeriksaan kembali untuk memastikan bahwa data tersebut telah bersih dari kesalahan. Analisis data terdiri dari analisis univariat dan bivariat. Pada analisis bivariat dicari hubungan antara dua variabel dengan menggunakan rumus chi -square. ${ }^{8}$ 
HASIL

\section{Karakteristik Responden}

Tabel 1. Data karakteristik penderita TB Paru pada Pengobatan Fase Intensif

\begin{tabular}{|c|c|c|c|}
\hline No & Karakteristik & $f$ & $\%$ \\
\hline \multirow[t]{3}{*}{1} & Jenis Kelamin & & \\
\hline & Laki-laki & 25 & 73,5 \\
\hline & Perempuan & 9 & 26,5 \\
\hline \multirow[t]{5}{*}{2} & Tingkat Pendidikan Terakhir & & \\
\hline & SD & 4 & 11,7 \\
\hline & SMP & 5 & 14,7 \\
\hline & SMA & 11 & 32,4 \\
\hline & Sarjana/ Akademik & 14 & 41,2 \\
\hline \multirow[t]{6}{*}{3} & Pekerjaan & & \\
\hline & Pegawai Swasta & 14 & 41,2 \\
\hline & Pegawai Negeri Sipil & 2 & 5,8 \\
\hline & Nelayan & 8 & 23,9 \\
\hline & Pedagang & 2 & 5,8 \\
\hline & Ibu Rumah Tangga & 4 & 11,7 \\
\hline
\end{tabular}

Berdasarkan Tabel 1, frekuensi dan distribusi jenis kelamin responden diketahui bahwa lebih dari separuh responden berjenis kelamin laki-laki yaitu sebesar 25 orang $(73,5 \%)$. Frekuensi dan distribusi tingkat pendidikan responden diketahui bahwa sebanyak 14 responden dengan pendidikan terakhir sarjana/ akademik (41,2\%).

\section{Hubungan Tingkat Kepatuhan Penderita TB Paru} dengan Tingkat Pengetahuan Penderita

Tabel 2. Hubungan tingkat kepatuhan penderita TB paru dengan tingkat pengetahuan penderita

\begin{tabular}{lccccc}
\hline \multirow{2}{*}{$\begin{array}{c}\text { Tingkat } \\
\text { Pengetahuan } \\
\text { Penderita }\end{array}$} & \multicolumn{3}{c}{ Tingkat Kepatuhan } & \\
\cline { 2 - 5 } & $\mathbf{2}$ Patuh & \multicolumn{3}{c}{ Tidak patuh } & $\mathrm{p}$ \\
\cline { 2 - 5 } & $\mathbf{f}$ & $\%$ & $\mathbf{f}$ & $\%$ & \\
\hline Baik & 18 & 90 & 2 & 10 & \\
Tidak Baik & 3 & 21,4 & 11 & 78,6 & 0,000 \\
Total & 21 & 61,8 & 13 & 38,2 & \\
\hline
\end{tabular}

Berdasarkan Tabel 2, Hasil uji statistik diperoleh nilai $p<0,05(p=0,000)$, yang berarti terdapat hubungan yang bermakna antara tingkat pengetahuan penderita dengan kepatuhan penderita TB paru.
3. Hubungan Tingkat Kepatuhan Penderita TB Paru dengan Sikap Responden

Tabel 3. Hubungan tingkat kepatuhan penderita TB paru dengan sikap responden

\begin{tabular}{|c|c|c|c|c|c|}
\hline \multirow{3}{*}{$\begin{array}{c}\text { Sikap } \\
\text { Responden }\end{array}$} & \multicolumn{4}{|c|}{ Tingkat Kepatuhan } & \multirow{3}{*}{$\mathbf{p}$} \\
\hline & \multicolumn{2}{|c|}{ Patuh } & \multicolumn{2}{|c|}{ Tidak patuh } & \\
\hline & $f$ & $\%$ & $f$ & $\%$ & \\
\hline Baik & 21 & 87,5 & 3 & 12,5 & \\
\hline Tidak Baik & 0 & 0 & 10 & 100 & 0,000 \\
\hline Total & 21 & 61,8 & 13 & 38,2 & \\
\hline
\end{tabular}

Berdasarkan Tabel 3, hasil uji statistik diperoleh nilai $p<0,05 \quad(p=0,000)$, yang berarti terdapat hubungan yang bermakna antara sikap penderita dengan kepatuhan penderita TB paru.

\section{Hubungan Tingkat Kepatuhan Penderita TB Paru dengan Peran Petugas Kesehatan}

Tabel 4. Hubungan tingkat kepatuhan penderita TB paru dengan peran petugas kesehatan

\begin{tabular}{|c|c|c|c|c|c|}
\hline \multirow{3}{*}{$\begin{array}{c}\text { Peran } \\
\text { Petugas } \\
\text { Kesehatan }\end{array}$} & \multicolumn{4}{|c|}{ Tingkat Kepatuhan } & \multirow{3}{*}{$\mathbf{p}$} \\
\hline & \multicolumn{2}{|c|}{ Patuh } & \multicolumn{2}{|c|}{ Tidak patuh } & \\
\hline & $f$ & $\%$ & $\mathbf{f}$ & $\%$ & \\
\hline Baik & 17 & 85 & 2 & 15 & \\
\hline Tidak Baik & 4 & 28,6 & 11 & 71,4 & 0,001 \\
\hline Total & 21 & 61,8 & 13 & 38,2 & \\
\hline
\end{tabular}

Berdasarkan Tabel 4, hasil uji statistik diperoleh nilai $p<0,05(p=0,001)$, yang berarti terdapat hubungan yang bermakna antara peran petugas kesehatan dengan kepatuhan penderita TB paru.

\section{Hubungan Tingkat Kepatuhan Penderita TB Paru dengan Efek Samping OAT}

Tabel 5. Hubungan tingkat kepatuhan penderita TB paru dengan efek samping OAT

\begin{tabular}{|c|c|c|c|c|c|}
\hline \multirow{3}{*}{$\begin{array}{c}\text { Efek Samping } \\
\text { OAT }\end{array}$} & \multicolumn{4}{|c|}{ Tingkat Kepatuhan } & \\
\hline & \multicolumn{2}{|c|}{ Patuh } & \multicolumn{2}{|c|}{ Tidak patuh } & \\
\hline & f & $\%$ & $\mathbf{f}$ & $\%$ & \\
\hline Ada & 18 & 60 & 12 & 40 & \\
\hline Tidak Ada & 3 & 75 & 1 & 25 & 0,562 \\
\hline Total & 21 & 61,8 & 13 & 38,2 & \\
\hline
\end{tabular}


Berdasarkan Tabel 5, dari hasil uji statistik tidak terdapat hubungan yang bermakna antara efek samping OAT dengan kepatuhan penderita TB paru dalam pengobatan, karena nilai $\mathrm{p}$ yang didapatkan > $0,05(p=0,562)$.

\section{Hubungan Tingkat Kepatuhan Penderita TB PARU dengan Peran PMO}

Tabel 6. Hubungan tingkat kepatuhan penderita TB paru dengan peran $\mathrm{PMO}$

\begin{tabular}{|c|c|c|c|c|c|}
\hline \multirow{3}{*}{ Peran PMO } & \multicolumn{4}{|c|}{ Tingkat Kepatuhan } & \multirow{3}{*}{$p$} \\
\hline & \multicolumn{2}{|c|}{ Patuh } & \multicolumn{2}{|c|}{ Tidak patuh } & \\
\hline & $f$ & $\%$ & $f$ & $\%$ & \\
\hline Baik & 19 & 90,5 & 2 & 9,5 & \\
\hline Tidak Baik & 2 & 15,4 & 11 & 84,6 & 0,000 \\
\hline Total & 21 & 61,8 & 13 & 38,2 & \\
\hline
\end{tabular}

Berdasarkan Tabel 6, hasil uji statistik diperoleh nilai $p<0,05(p=0,000)$, yang berarti terdapat hubungan yang bermakna antara peran PMO dengan kepatuhan penderita TB Paru.

\section{PEMBAHASAN}

Hubungan tingkat kepatuhan penderita TB paru dengan tingkat pengetahuan penderita dalam pengobatan

Berdasarkan hasil uji statistik diperoleh nilai $p<$ $0,05(p=0,000)$, yang berarti ada hubungan yang bermakna antara tingkat pengetahuan dengan kepatuhan penderita TB paru. Hasil penelitian ini sejalan dengan Erni et al pada tahun 2009, dijelaskan bahwa pengetahuan penderita yang sangat rendah dapat menentukan ketidakpatuhan penderita minum obat karena kurangnya informasi yang diberikan oleh petugas kesehatan tentang penyakit TB paru, cara pengobatan, bahaya akibat tidak teratur minum obat dan pencegahannya. ${ }^{9}$

Dalam penelitian ini masih banyak responden menganggap tidak perlu meneruskan pengobatan hingga selesai karena perbaikan klinis yang dirasakan responden. Faktor- faktor yang dapat mempengaruhi pengetahuan seseorang adalah faktor internal (minat, kondisi fisik, intelegensia), faktor eksternal (keluarga, masyarakat, sarana). Namun, dalam penelitian ini, minat beberapa responden untuk mendengarkan penyuluhan TB paru cenderung kurang. ${ }^{10}$
Hubungan tingkat kepatuhan penderita TB paru dengan sikap responden dalam pengobatan

Secara analitik statistik berdasarkan uji chisquare diperoleh nilai $p<0,05(p=0,000)$, yang berarti ada hubungan yang bermakna antara sikap responden dengan kepatuhan penderita TB paru.Dalam penelitian ini, responden mempunyai keinginan untuk menambah pengetahuannya mengenai penyakit TB paru, tetapi sering dihalangi oleh berbagai alasan sehingga tidak dapat mendengarkan penyuluhan secara langsung.

Sikap responden dipengaruhi oleh pengetahuan yang dimiliki oleh responden mengenai penyebab, penularan dan pencegahan penyakit TB paru. ${ }^{10}$

\section{Hubungan tingkat kepatuhan penderita TB paru dengan peran petugas kesehatan dalam pengobatan}

Hasil uji statistik diperoleh nilai $p<0,05 \quad(p=$ 0,001), yang berarti terdapat hubungan yang bermakna antara peran petugas kesehatan dengan kepatuhan penderita TB paru. Penelitian yang dilakukan oleh Annisa pada tahun 2012 di Kabupaten Lima Puluh Kota mendapatkan hasil yang berbeda. Hasil penelitian tersebut didapatkan bahwa tidak terdapat hubungan yang bermakna antara petugas kesehatan dengan kepatuhan penderita TB paru. ${ }^{11}$

Dalam penelitian ini, didapatkan peran petugas kesehatan pada umumnya masih kurang baik dalam hal memberi informasi TB paru kepada responden. Berdasarkan hasil wawancara dengan responden, diketahui bahwa petugas kesehatan hanya sebagian yang memberikan penyuluhan mengenai jadwal menelan obat dan mengambil obat, pencegahan, penularan dan pentingnya PMO kepada responden ketika datang untuk mengambil obat pertama kali.

Hubungan tingkat kepatuhan penderita TB paru dengan efek samping OAT dalam pengobatan

Hasil uji statistik menunjukkan tidak terdapat hubungan yang bermakna antara efek samping OAT dengan kepatuhan penderita TB paru dalam pengobatan, karena nilai $p$ yang didapatkan $>0,05$ $(p=0,562)$. Berbeda dengan hasil penelitian yang dilakukan oleh Samsurian yang dilakukan pada tahun 
2011, dimana hasil penelitian yang didapat bahwa terdapat pengaruh efek samping OAT terhadap kepatuhan berobat TB paru. Hasil analisisnya didapatkan bahwa penderita TB paru yang mempunyai keluhan efek samping OAT berisiko besar 2,84 kali untuk terjadinya ketidakpatuhan berobat dibandingkan yang tidak memiliki keluhan. ${ }^{12}$

Dalam penelitian ini, sebagian responden mengalami efek samping OAT, tetapi tetap patuh dalam berobat akibat dipengaruhi oleh variabel lain. Selain dari itu, responden yang mengalami efek samping OAT dan tidak patuh dalam berobat, berdasarkan hasil wawancara disebabkan karena sebagian responden tidak mengetahui bahwa OAT dapat menimbulkan keluhan.

\section{Hubungan tingkat kepatuhan penderita TB paru dengan peran PMO dalam pengobatan}

Hasil uji statistik diperoleh nilai $p<0,05$ $(p=0,000)$, yang berarti terdapat hubungan yang bermakna antara peran PMO dengan kepatuhan penderita TB Paru. Hasil penelitian ini didukung oleh Annisa pada tahun 2012. Berdasarkan hasil penelitian tersebut didapatkan bahawa ada pengaruh yang signifikan antara peran PMO terhadap kepatuhan berobat penderita TB paru. Keberadaan PMO sangat diperlukan untuk meningkatkan kepatuhan penderita, yaitu untuk mengingatkannya minum obat atau pun mengambil obat ke Puskesmas. ${ }^{11}$

Dukungan keluarga dan masyarakat sebagai pengawas dan pemberi semangat kepada penderita mempunyai peran yang sangat besar dalam peningkatan pengobatan penderita. Hasil wawancara dengan beberapa responden menunjukkan bahwa beberapa peran PMO masih rendah dalam pengawasan menelan obat dan kontrol secara teratur. Hal ini kemungkinan disebabkan oleh masih kurangnya pengetahuan PMO dalam hal mengenai pentingnya PMO bagi penderita TB paru dan penyuluhan TB paru. ${ }^{7}$

\section{SIMPULAN}

Tingkat kepatuhan berobat penderita TB paru dipengaruhi oleh perilaku kesehatan (tingkat ilmu pengetahuan, sikap, dan peran petugas kesehatan) dan peran dari PMO.

Tidak terdapat hubungan yang bermakna antara efek samping dari OAT terhadap tingkat kepatuhan penderita TB paru pada pengobatan fase intensif.

\section{DAFTAR PUSTAKA}

1. Aditama, Tjandra Y. Tuberkulosis: diagnosis, terapi dan masalahnya. Edisi ke-5. Yayasan Penerbit Ikatan Dokter Indonesia. Jakarta; 2005.hIm.37-48.

2. Kemenkes Republik Indonesia. Strategi nasional pengendalian TB di Indonesia 2010-2014. Dirjen PP \& PL. Jakarta; 2011.hlm.12-30.

3. Dinas Kesehatan Kota Padang. Jumlah kasus baru TB paru dan kematian akibat TB paru menurut jenis kelamin, kecamatan dan puskesmas Kota Padang tahun 2011. Resume Profil Kesehatan Kota Padang tahun 2011. Padang; 2011.hlm.1720.

4. Departemen Kesehatan Republik Indonesia. Pedoman nasional penangggulangan tuberkulosis. Direktorat Jenderal Pengendalian Penyakit dan Penyehatan Lingkungan. Jakarta; 2011.hlm.2-30.

5. Dinas Kesehatan Kota Padang. Jumlah kasus baru TB paru dan kematian akibat TB paru menurut jenis kelamin, kecamatan dan puskesmas Kota Padang tahun 2011. Resume Profil Kesehatan Kota Padang tahun 2011. Padang;2011.hlm.17-20.

6. Badan Litbang Kesehatan. Laporan Hasil Riset Kesehatan Dasar. Badan Litbang Kesehatan. Jakarta; 2010.hlm.333-50.

7. Tirtana B. Faktor-faktor yang mempengaruhi keberhasilan pengobatan pada pasien tuberkulosis paru dengan resistensi obat tuberkulosis di wilayah Jawa Tengah (skripsi). Semarang: Fakultas Kedokteran Universitas Dipenogoro; 2011.

8. Sastroasmoro S. Dasar-dasar metodologi penelitian klinis. Edisi ke-2. Jakarta: CV Sagung Seto; 2002.hlm.67-166.

9. Erni E, Purwanta, Heru S. Faktor-faktor yang mempengaruhi ketidakpatuhan berobat pada penderita tuberkulosis paru. Dalam Berita Kedokteran Masyarakat UGM. 2009;25(3):117-24. 
10. Notoadmojo S. Promosi kesehatan dan ilmu perilaku. Jakarta: Rineka Cipta; 2007.hlm.72-85.

11. Annisa F. Hubungan tingkat pengetahuan penderita, peran petugas kesehatan dan peran pengawas menelan obat (PMO) dengan kepatuhan penderita TB paru dalam pengobatan di Puskesmas Muaro Bungo Lima Puluh Kota Tahun
2012 (skripsi). Padang: Fakultas Kesehatan Masyarakat Universitas Andalas; 2012.

12. Samsurian. Pengaruh efek samping obat anti tubekulosis terhadap kejadian default di rumah sakit islam Pondok Kopi Jakarta Timur Januari 2008-Mei 2010 (tesis).Jakarta: Fakultas Kesehatan Masyarakat Univesitas Indonesia; 2010. 